\title{
Synthesis, characterization and anticancer activity of selenium nanobiocomposite of L-asparaginase
}

\author{
G BASKAR* (1D, K LALITHA and GARRICK BIKKU GEORGE \\ Department of Biotechnology, St. Joseph's College of Engineering, Chennai 600 119, India \\ *Author for correspondence (basg2004@gmail.com)
}

MS received 22 November 2017; accepted 4 April 2018; published online 5 January 2019

\begin{abstract}
Selenium is a rare earth nonmetal and an essential micronutrient for animals, and a trace nutrient for humans. It is known to function as a cofactor for reduction of antioxidant enzymes, such as glutathione peroxidase. The selenium nanobiocomposite synthesized using a co-precipitation method with sizes 20-30 nm were confirmed using scanning electron microscopy and they showed maximum absorption between 300 and $400 \mathrm{~nm}$ in the ultra-violet spectrum. Fourier transform infrared and H-nuclear magnetic resonance analysis revealed the involvement of various functional groups in the binding of asparaginase to selenium nanoparticles to form the selenium nanobiocomposite. X-ray diffraction analysis confirmed the hexagonal structure of the selenium nanobiocomposite. Methylthiazolyl diphenyl-tetrazolium bromide assay on HT-29, MG-63 and HEPTO cells loaded with the selenium nanobiocomposite revealed a toxicity of $93.62,94.24$ and $87.68 \%$, respectively, for a selenium nanobiocomposite concentration of $1000 \mu \mathrm{g} \mathrm{ml}^{-1}$. The selenium nanobiocomposite of L-asparaginase opens a new arena in cancer treatment.
\end{abstract}

Keywords. Selenium nanobiocomposite; asparaginase; anticancer activity; colon cancer; human osteosarcoma; liver cancer.

\section{Introduction}

Metal nanoparticles are used as effective nanocarriers for targeted delivery of anticancer drugs to cancer cells. Thus, the use of nanocarriers increases drug efficacy by prolonging their therapeutic effect and also decreases drug dosage $[1,2]$. Metal nanoparticles such as zinc-oxide nanoparticles, iron-oxide nanoparticles, copper-oxide nanoparticles, silver nanoparticles and gold nanoparticles are used as nanocarriers for therapeutic applications [3-5]. Selenite $\left(\mathrm{s}^{4+}\right)$ and selenite $\left(\mathrm{s}^{6+}\right)$ are the commonly available forms of selenium in the Earth's crust. It has different allotropic forms among which black crystalline trigonal having helical chains is widely used [6]. Electronic industries have been using selenium for manufacturing rectifiers, photoelectric cells etc. In glass and ceramic industries, they act as decolorizers; on the other hand they are used as pigments in paint industry supporting their multifarious applications [7]. Selenium nanoparticles have known to treat colon and prostate cancer in the past. Biosynthesized selenium nanorods from Streptomyces bikiniesis reported to have $\mathrm{LD}_{50}$ of 75.96 and $61.86 \mu \mathrm{g} \mathrm{ml}^{-1}$ on HepG2 and MCF-7 cell lines, respectively, supporting efficacy in cancer treatment [8].

Antimicrobial activity of biosynthesized selenium nanoparticles showed $99 \%$ toxicity on Pseudomonas aeruginosa, Staphylococcus aureus, Escherichia coli and Streptococcus pyogenes, compared with ampicillin [9]. The nanoform of selenium has gained momentum over the bulk form due to its lower toxicity, high reactivity and low dosage forms. Selenium enriched Lactobacillus was known to enhance the lifespan of cancer bearing animals [10]. Selenium nanoparticles $(50 \mathrm{~nm})$ synthesized from a fenugreek seed extract was reported to inhibit the growth of MCF-7 cells [11]. Folic acid-coated selenium nanoparticles $(70 \mathrm{~nm})$ were found to be internalized by endocytosis into mitochondria of MCF-7 cells thereby accelerating mitochondria-mediated apoptosis of MCF-7 cells supporting its usage in breast cancer treatment [12]. The use of selenium nanoparticles in early intervention and treatment of breast, lung, colon and prostate cancers is indicative of its importance in cancer treatment. Selenium reacts with membrane peroxidase to release free radicals and reactive oxygen species leading to apoptosis of cancer cells. Inorganic forms of selenium such as sodium selenite selectively destroy the mitochondria of cancer cells, but not those of healthy cells by increasing the activity of the enzyme glutathione peroxidase conferring protection. Damaged DNA segments in healthy tissues can be repaired by selenium therapy by preventing DNA segments reverting to cancerous stage. Treatment with selenium nanoparticles suppresses the expression level of protein B-cell lymphoma 2 in cancer cells hampering its differentiation and proliferation.

Selenium nanobiocomposites of L-asparaginase will provide synergetic effect in killing cancer cells due to the inherent anticancer properties of L-asparaginase combined with selenium nanoparticles. Asparaginase is a hydrolase enzyme with enzyme commission (EC) number 3.5.1.1. 
Asparaginase catalyses the asparagine present on the surface of cancer cells to L-aspartate and ammonia thereby reducing their concentration on the cell surface [13]. Normal cells can synthesize intracellular L-asparagine from aspartic acid and glutamine using asparagine synthetase. However, tumour cells lack the cellular mechanism to synthesize intracellular L-asparagine due to the damaged DNA mechanism. Thus, the tumour cells become depleted of the L-asparagine on their cell surface. This leads to the death of tumour cells on treating with L-asparaginase as L-asparagine is a crucial amino acid for activation and proliferation of tumour cell by acting as an amino acid exchange factor $[14,15]$. The current work was focused on synthesis of the selenium nanobiocomposite of L-asparaginase for use as a drug for various cancers.

\section{Materials and methods}

\subsection{Chemicals required}

Silver nitrate, dimethyl sulphoxide (DMSO), trypsin and methylthiazolyl diphenyl-tetrazolium bromide (MTT) were purchased from SRL Chemicals, Mumbai, India. Trisodium citrate was purchased from LOBA Chemicals, India and fluorescein isothiocyanate (FITC) was purchased from HiMedia Laboratories, Mumbai, India. All chemicals were used without further purification. The strain Aspergillus terreus MTCC1782 used in the production of L-asparaginase was obtained from the Institute of Microbial Technology, Chandigarh, India. MG-63, HEPTO and HT-29 cell lines were obtained from NCCS, Pune. Minimum essential media (MEM) was purchased from Hi-Media Laboratories, India. Fetal bovine serum (FBS) was purchased from Cistron Laboratories, India. All other chemicals and reagents were obtained from Sigma-Aldrich, Bangalore, India.

\subsection{Chemical synthesis of selenium nanoparticles}

Equal volumes of $100 \mathrm{mM}$ sodium selenite and $50 \mathrm{mM}$ $\beta$-mercaptoethanol were taken. The $\beta$-mercaptoethanol was added to sodium selenite dropwise with continuous stirring. The colour change was observed from dark orange to light orange/brown indicating the formation of selenium nanoparticles. The nanoparticle solution was centrifuged at $4300 \mathrm{rpm}$ for $30 \mathrm{~min}$. The supernatant was discarded and the pellet was washed with de-ionized water and dried [16].

\subsection{Production of L-asparaginase}

A. terreus strain was cultivated in Czapek-Dox agar slants at $37^{\circ} \mathrm{C}$ for 4 days. A. terreus was inoculated in a $250 \mathrm{ml}$ Erlenmeyer flask containing $100 \mathrm{ml}$ of modified Czapek-Dox liquid medium containing $2.0 \mathrm{~g}$ L-proline, $1.0 \mathrm{~g}$ L-asparagine, $0.2 \mathrm{~g}$ glucose, $1.0 \mathrm{~g}$ sodium nitrate, $0.052 \mathrm{~g}$ potassium chloride, $1.52 \mathrm{~g}$ dipotassium hydrogen phosphate, $0.001 \mathrm{~g}$ zinc sulphate, $0.001 \mathrm{~g}$ ferrous sulphate and $0.052 \mathrm{~g}$ magnesium sulphate maintained at $\mathrm{pH}$ 6.2. The fungus was grown in autoclave-modified Czapek-Dox liquid medium aerobically in an orbital shaker at $160 \mathrm{rpm}, 32^{\circ} \mathrm{C}$ for 3 days. After the incubation period, the culture medium was filtered using Whatman \#1 filter paper; the filtrate rich in L-asparaginase was collected for further use [17].

\subsection{Estimation of L-asparaginase activity and protein}

Crude asparaginase $(0.1 \mathrm{ml})$ was added to $0.9 \mathrm{ml}$ of $0.1 \mathrm{M}$ phosphate buffer ( $\mathrm{pH} \mathrm{8.5)}$ along with $1 \mathrm{ml}$ of $0.04 \mathrm{M} \mathrm{L-}$ asparaginase and incubated at $37^{\circ} \mathrm{C}$ for $10 \mathrm{~min}$. The reaction was stopped by adding $0.5 \mathrm{ml}$ of $15 \%$ trichloroacetic acid, and centrifuged at $6000 \mathrm{rpm}$ for $10 \mathrm{~min}$ at $4^{\circ} \mathrm{C}$. $0.1 \mathrm{ml}$ of supernatant was taken and diluted to $8 \mathrm{ml}$ with distilled water. $1 \mathrm{ml}$ of $2 \mathrm{M} \mathrm{NaOH}$ and $1 \mathrm{ml}$ of Nessler's reagent were added and incubated for $10 \mathrm{~min}$ at room temperature. Optical density (OD) was taken at $480 \mathrm{~nm}$ [18]. The protein concentration was estimated using Bradford's method [19].

\subsection{MTT assay for estimating anticancer activity of nanobiocomposites of selenium-oxide nanoparticles}

The MTT assay is based on the ability of live but not dead cells to reduce a yellow tetrazolium dye to a purple formazan product. The cells were maintained in MEM. Cells $\left(1 \times 10^{5}\right.$ per well) were plated in 24 -well plates and incubated at $37^{\circ} \mathrm{C}$ with $5 \% \mathrm{CO}_{2}$. After the cells reached confluence, various concentrations of the samples were added and incubated for another $24 \mathrm{~h}$. After incubation, the samples were removed from the well and washed with phosphate-buffered saline (PBS, pH 7.4) or MEM without serum $100 \mu \mathrm{l}$ per well $\left(5 \mathrm{mg} \mathrm{ml}^{-1}\right)$ of $0.5 \%$ MTT was added and incubated for another $4 \mathrm{~h}$ [20]. After incubation, $1 \mathrm{ml}$ of DMSO was added to the wells. The absorbance was measured at $570 \mathrm{~nm}$ with a UV spectrophotometer using DMSO as the blank. The concentration of the sample required to kill $50 \%$ of cell population $\left(\mathrm{IC}_{50}\right)$ was determined graphically. The \% cell viability was calculated using equation (1):

$$
\begin{aligned}
& \% \text { Cell viability } \\
& \left.=\left(\left(A_{570} \text { of treated cells } / A_{570} \text { of control cells }\right) \times 100\right)\right) .
\end{aligned}
$$

A graph was plotted taking \% cell viability in the $Y$-axis and concentration of the sample in the $X$-axis. Cell control and sample control were included in each assay to compare the full cell viability assessments.

\subsection{Synthesis of nanobiocomposites of selenium-oxide nanoparticles and fungal L-asparaginase bound to FITC}

Selenium nanoparticles $(0.4 \mathrm{~g})$ were mixed with $400 \mathrm{ml}$ of phosphate buffer ( $\mathrm{pH} 8.5$ ). $4 \mathrm{ml}$ of glutaraldehyde was added to nanoparticle solution and stirred for $2 \mathrm{~h}$ at $30^{\circ} \mathrm{C} .0 .004 \mathrm{~g}$ 
of FITC was dissolved in $4 \mathrm{ml}$ of DMSO $\left(1 \mathrm{mg} \mathrm{ml}^{-1}\right) .970 \mu \mathrm{l}$ of FITC solution was taken and mixed with $200 \mathrm{ml}$ of asparaginase along with glutaraldehyde pre-treated nanoparticle solution and stirred for $30 \mathrm{~min}$ at $4^{\circ} \mathrm{C}$. Then, the solution was stored at $4^{\circ} \mathrm{C}$ for $6 \mathrm{~h}$, and later centrifuged at $5000 \mathrm{rpm}$ for $30 \mathrm{~min}$. The supernatant was discarded and the pellet was washed with de-ionized water and dried at $70^{\circ} \mathrm{C}$ for $5 \mathrm{~h}$.

\subsection{Fluorescent microscopic study of selenium-oxide nanobiocomposite of L-asparaginase bound to FITC}

HEPTO cells were seeded with (1 lakh cells per ml) on a cover slip placed in a 6-well plate and incubated for $24 \mathrm{~h}$. After incubation, the monolayers of cells were treated with $\mathrm{IC}_{50}$ concentration of the selenium nanobiocomposite labelled with FITC and incubated for $24 \mathrm{~h}$. The treated cells were washed with sterile PBS. $70 \%$ ethanol was used to fix the cells. $0.2 \mathrm{ml}$ of propidium iodide $\left(10 \mu \mathrm{g} \mathrm{ml}^{-1}\right)$ was added to the cells and left for 15-30 min. The cover slip containing the stained cells was removed from the 6-well plates and placed on a clean, grease-free glass slide and fluorescent images of HEPTO cells were obtained.

\section{Results and discussion}

\subsection{Visual and ultra-violet $(U V)$ spectroscopic confirmation}

Transformation of a white metal precursor sodium selenite solution to a dark orange/light brown colour solution on addition of $\beta$-mercaptoethanol indicated the formation of grey colour selenium nanoparticles. A characteristic peak was observed in the UV spectrum at $320 \mathrm{~nm}$ confirming the presence of selenium nanoparticles and the peak at $440 \mathrm{~nm}$ confirmed the formation of selenium nanobiocomposite of asparaginase.

\subsection{Asparaginase activity}

The activity of L-asparaginase was increased from 5.17 to $29.54 \mathrm{IU} \mathrm{ml}^{-1}$ in a selenium nanobiocomposite, however the activity was reduced to 15.14 from $21.543 \mathrm{IU} \mathrm{ml}^{-1}$ for the selenium nanobiocomposite bound to FITC. This might be because of the active site of the asparaginase involved in binding with selenium-oxide nanoparticles and FITC. Binding efficiency of asparaginase was found by calculating the ratio of 'total protein bound to nanoparticles' to 'total protein taken for binding'. A = Protein bound to nanoparticles $=\left(\right.$ Protein concentration in nanoparticles $\left(\mathrm{mg} \mathrm{ml}^{-1}\right) \times$ total volume of nanoparticle suspension). $\mathrm{B}=$ Total protein available for binding $=$ (Protein concentration in crude enzyme $\left(\mathrm{mg} \mathrm{ml}^{-1}\right) \times$ volume of crude asparaginase taken for binding). The binding efficiency of $73.69 \%$ for asparaginase was obtained.

\subsection{Scanning electron microscopy (SEM) and energy dispersive $X$-ray (EDAX) analysis of selenium nanobiocomposite of asparaginase}

The SEM image of the selenium nanobiocomposite (figure 1) was obtained at $24 \mathrm{kV}$ power setting and $500 \mathrm{~nm}$ in high-vacuum mode at $1,60,000 \times$. The surface was uniform and smooth with an average particle size of 20-30 nm. The selenium nanoparticles were hexagonal. The EDAX analysis (figure 2) revealed the presence of the Se peak at 1.4 and $11.1 \mathrm{keV}$ which confirms the reduction of sodium selenite to selenium nanoparticles. From the elemental analysis it was observed that the element selenium ranks first with a weight percentage of $94.19 \%$.

\subsection{Fourier transform infrared (FTIR) analysis of selenium nanoparticles and selenium nanobiocomposite}

The interaction between selenium nanoparticles and asparaginase was observed using FTIR spectroscopic analysis. The FTIR spectrum was observed from 400 to $3800 \mathrm{~cm}^{-1}$ (figure 3). The peaks located at 3400 and $2800 \mathrm{~cm}^{-1}$ indicate the strong binding of alcohol $(\mathrm{O}-\mathrm{H})$ and carbonyl (O-H) stretch vibrations. From 3000 to $2800 \mathrm{~cm}^{-1}$ strong

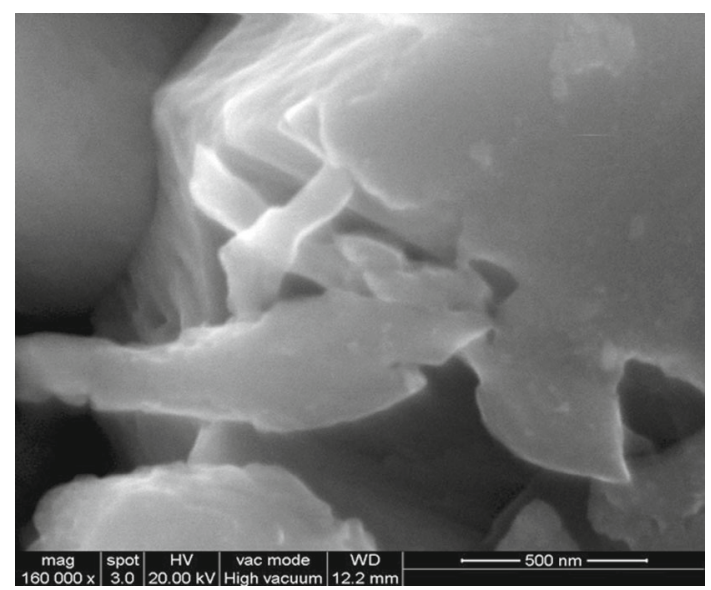

Figure 1. SEM image of the selenium nanobiocomposite.

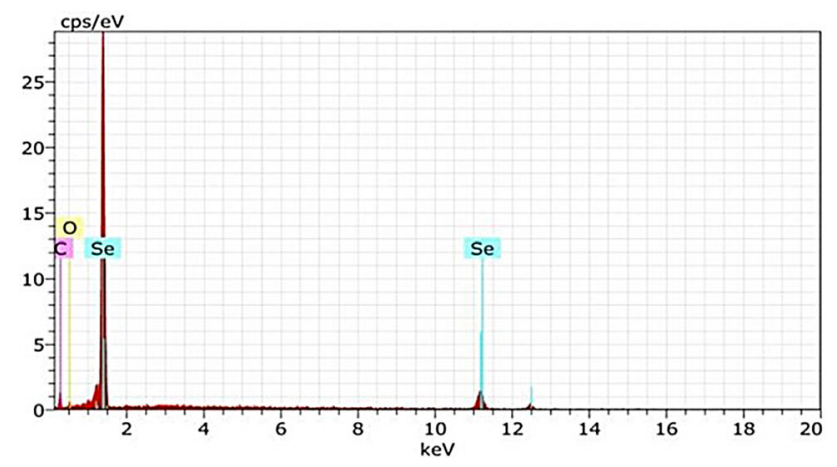

Figure 2. EDAX spectrum of the selenium nanoparticles. 


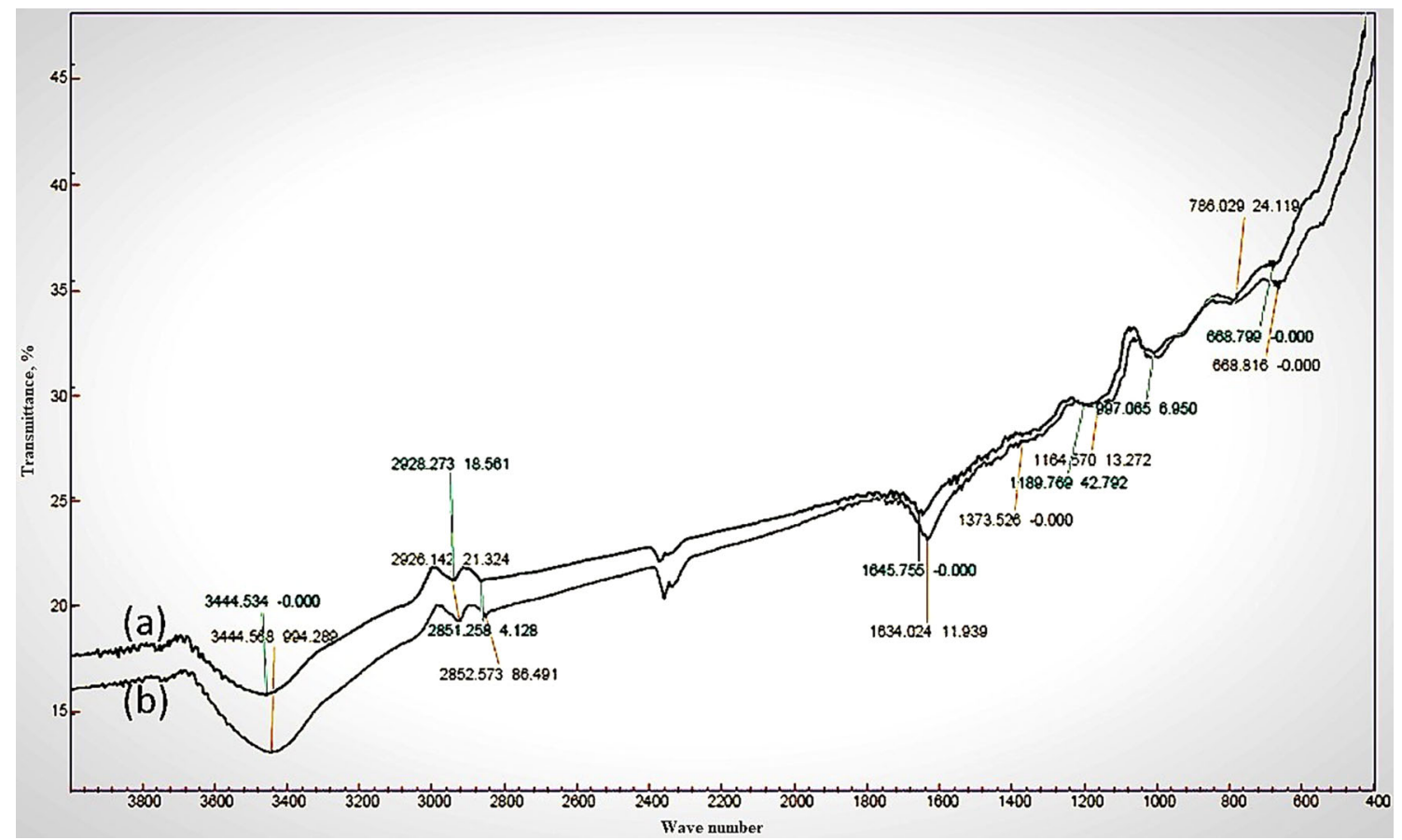

Figure 3. FTIR spectrum of (a) selenium nanoparticles and (b) selenium nanobiocomposite.

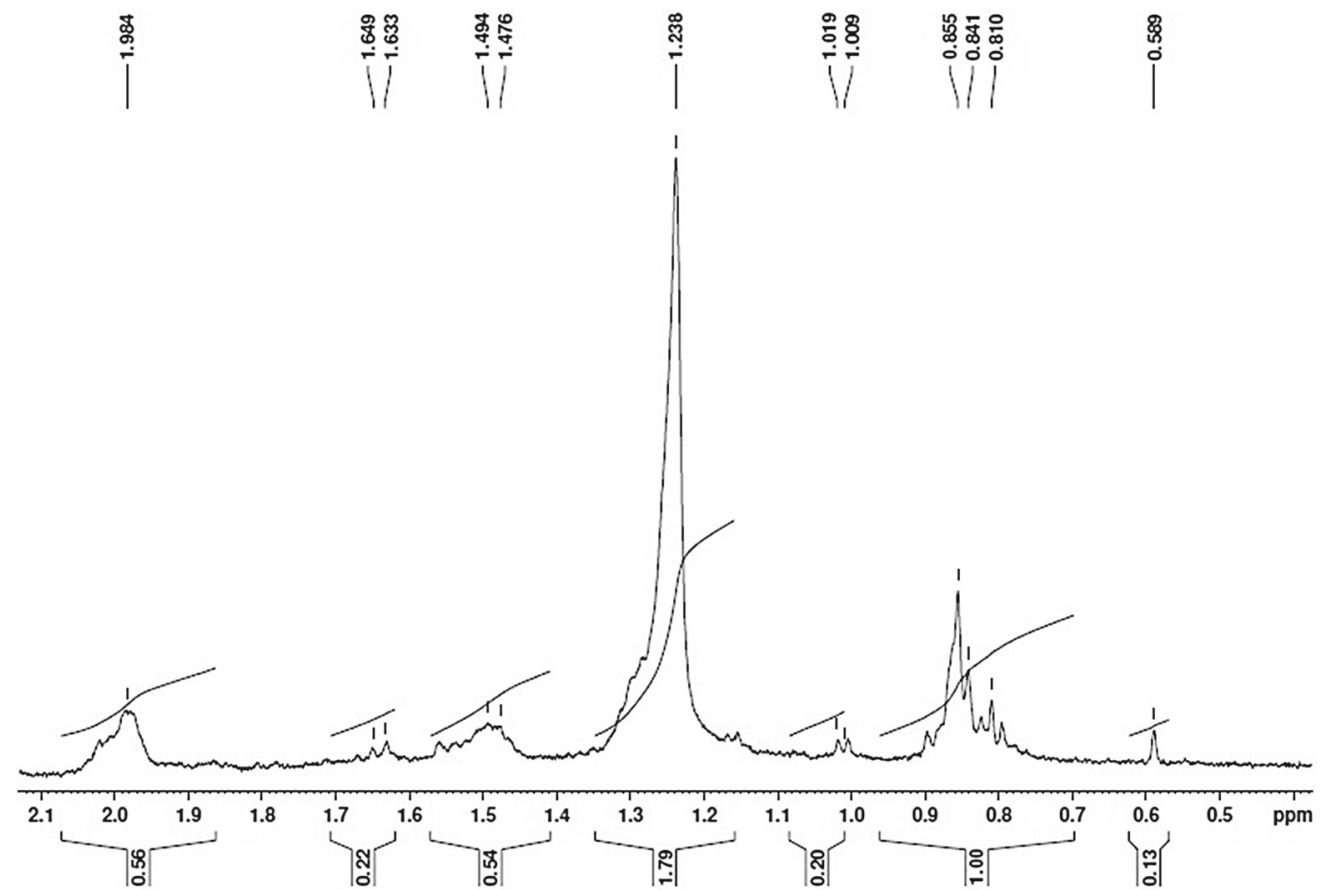

Figure 4. H-NMR spectrum of the selenium nanobiocomposite.

alkene $(\mathrm{C}-\mathrm{H})$ stretch vibrations were observed. The peak at $1600 \mathrm{~cm}^{-1}$ indicates the presence of the amine $(\mathrm{N}-$ H) stretch vibration. From 1400 to $1200 \mathrm{~cm}^{-1}$ multiple band aromatic $(\mathrm{C}=\mathrm{C})$ bonds were observed having medium stretch vibrations. From figure $3 \mathrm{a}$ and $\mathrm{b}$ corresponding to selenium nanoparticles and selenium nanobiocomposite, it can be inferred that the carbonyl carbon groups are involved in the binding of selenium nanoparticles with asparaginase. 


\subsection{H-nuclear magnetic resonance (H-NMR) analysis of selenium nanobiocomposite}

The H-NMR spectrum of the selenium nanobiocomposite in terms of chemical shift and their corresponding functional groups is presented in figure 4 . The minor singlet peak at $0.6 \mathrm{ppm}$ and multiple peaks ranging between 0.7 and $0.9 \mathrm{ppm}$ represented the presence of the primary alkyl group. Minor doublet peaks ranging between 1.0 and $1.1 \mathrm{ppm}$ and strong narrow singlet peaks between 1.2 and $1.3 \mathrm{ppm}$ indicated the presence of the secondary alkyl groups. Minor multiple peaks

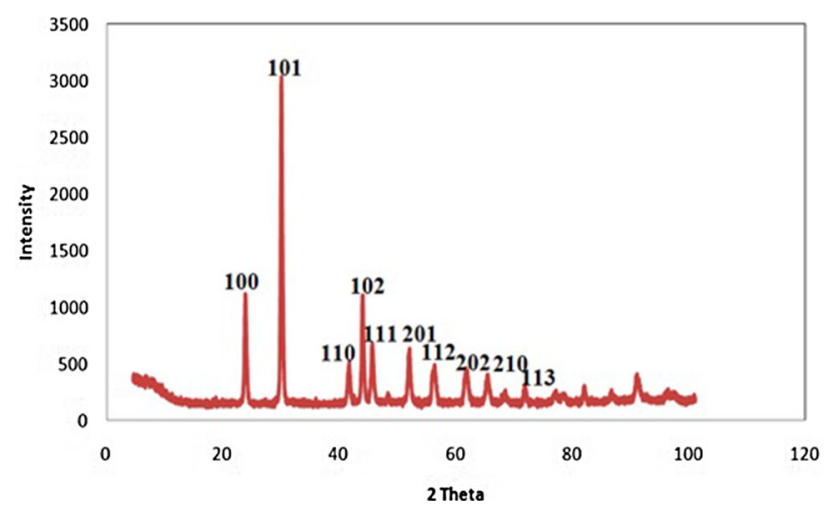

Figure 5. XRD spectrum of the selenium nanobiocomposite.

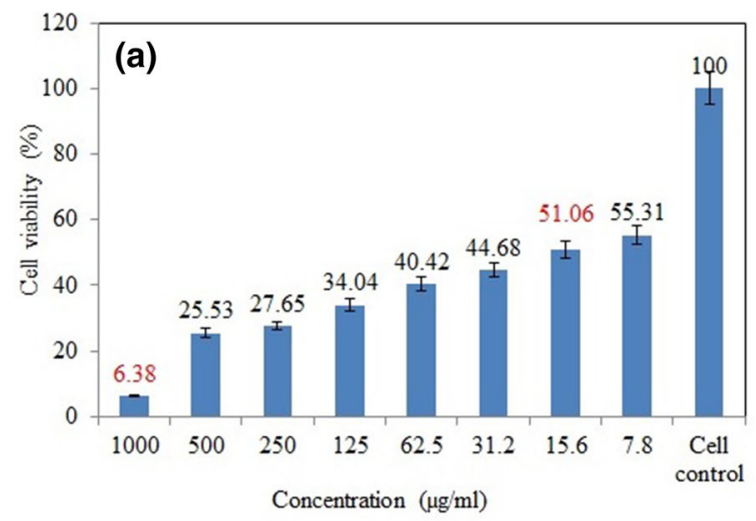

between 1.4 and $1.6 \mathrm{ppm}$ revealed the presence of the tertiary alkyl group. Minor doublet peaks ranging between 1.6 and $1.7 \mathrm{ppm}$ and singlet peak between 1.9 and $2.1 \mathrm{ppm}$ revealed the presence of the allylic carbon group. From the above interpretation, it can be confirmed that primary, secondary alkyl groups and allylic carbon are involved in the binding of asparaginase to selenium nanoparticles to form the selenium nanobiocomposite.

\subsection{X-ray diffraction (XRD) analysis of selenium nanobiocomposite}

The crystal structure of the selenium nanobiocomposite was analysed using XRD (figure 5). The 2-theta values of the peaks were indexed using JCPDS file no. 06-0362 and corresponded to the following planes of the selenium crystal. The indexed planes corresponded to the phase hexagonal structure of the selenium asparaginase nanobiocomposite. The sharpness of the peaks indicated that the selenium nanobiocomposite was in the pure crystalline phase. The average particle size of the nanobiocomposite was calculated using the Scherrer formula given in equation (2):

$$
D_{\mathrm{p}}=(0.98 \times \lambda / \beta \times \cos \theta)
$$

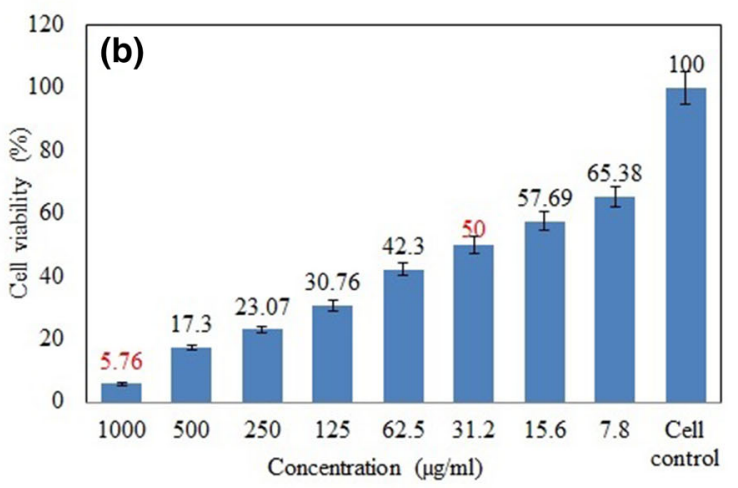

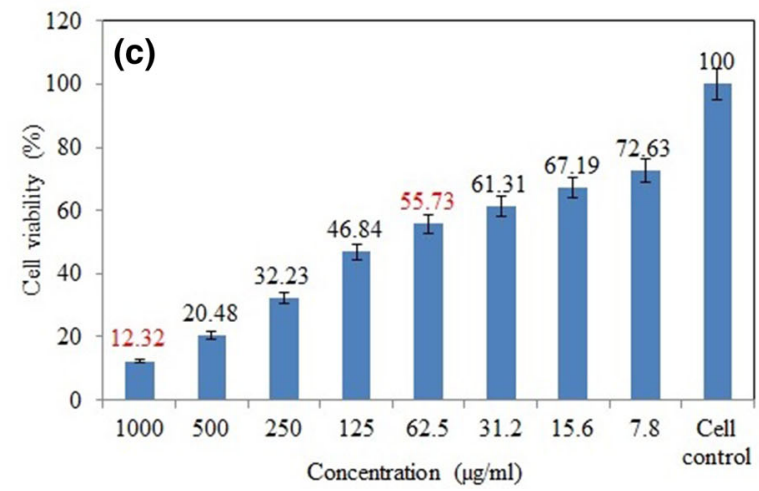

Figure 6. Effect of varied concentration of the selenium nanobiocomposite on cell viability of (a) HT-29 cell line, (b) MG-63 cell line and (c) HEPTO cell line. 
where $D_{\mathrm{p}}$ is the average crystalline size, $\lambda$ is the wavelength of the $\mathrm{Cu} \mathrm{K} \alpha$ line which is equal to $1.54 \mathrm{~nm}, \theta$ is the Bragg angle $\left(29.99^{\circ}\right)$ and $\beta$ is the full-width at half-maximum (FWHM) of the diffraction peak in radians.

\subsection{Cell viability by MTT assay}

The anticancer activity of the selenium nanobiocomposite of asparaginase was tested on MG-63 (human osteosarcoma), HT-29 (colon cancer) and HEPTO (liver cancer) cell lines. The cells were maintained in MEM supplemented with $10 \% \mathrm{FBS}$, penicillin $\left(100 \mathrm{U} \mathrm{ml}^{-1}\right)$ and streptomycin $\left(100 \mu \mathrm{g} \mathrm{ml}^{-1}\right)$ under a humidified atmosphere of $50 \mu \mathrm{g} \mathrm{ml}^{-1} \mathrm{CO}_{2}$ at $37^{\circ} \mathrm{C}$. Cell control and sample control were included in each assay to compare the full cell viability assessments. The selenium nanobiocomposite was prepared in known concentrations ranging from 1000 to $7.8 \mu \mathrm{g} \mathrm{ml}^{-1}$ and in various dilutions starting from $1: 1$ to 1:64. The selenium nanobiocomposite showed cell viability of $6.38 \%$ for $1000 \mathrm{~m} \mathrm{ml}^{-1}$ and $\mathrm{IC}_{50}$ value of $51.06 \%$ for $15.6 \mu \mathrm{g} \mathrm{ml}^{-1}$ on the HT-29 cell line (figure 6a). In contrast, cell viability was found to be $5.76 \%$ (increase by $0.62 \%$ ) for $1000 \mu \mathrm{g} \mathrm{ml}^{-1}$ on MG-63 (figure 6b) as compared with that on the HT-29 cell line. The $\mathrm{IC}_{50}$ value was found to be $50 \%$ for $31.2 \mu \mathrm{g} \mathrm{ml}^{-1}$ for the MG-63 cell line. The viability of $12.32 \%$ for $1000 \mu \mathrm{g} \mathrm{ml}^{-1}$ and $\mathrm{IC}_{50}$ value of $55.73 \%$ was observed for $125 \mu \mathrm{g} \mathrm{ml}^{-1}$ on the HEPTO cell line (figure $6 \mathrm{c})$. An increase in the concentration of the selenium nanobiocomposite $1000-7.8 \mu \mathrm{g} \mathrm{ml}^{-1}$ led to a considerable decrease in viability of the cells to as low as 6.38, 5.76 and $12.32 \%$ on HT-29, MG-63 and HEPTO cell lines, respectively. From these interpretations, it can be confirmed that selenium nanobiocomposite works best on HT-29 (colon cancer) and MG-63 (human osteosarcoma) cell lines with $\mathrm{IC}_{50}$ values of 15.6 and $31.2 \mu \mathrm{g} \mathrm{ml}^{-1}$. At higher concentration $\left(1000 \mu \mathrm{g} \mathrm{ml}^{-1}\right)$ cell viability was found to be 6.38 and $5.76 \%$ on HT-29 (colon cancer) and MG-63 (human osteosarcoma) cell lines and slightly higher value of $12.32 \%$ on HEPTO cell line supporting its efficacy in treating above cancers.

\subsection{Fluorescent microscopic study of selenium nanobiocomposite on HEPTO cell line}

The selenium nanobiocomposite of asparaginase labelled with FITC was targeted efficiently and internalized through cooperative binding (endocytosis) without prolonged attachment to the cell membrane due to the large size $(20-30 \mathrm{~nm})$ of the synthesized selenium nanoparticles. Due to the strong columbic interactions between the positively charged surface of the nanoparticles and the negatively charged plasma membrane, the spherical shape of selenium nanobiocomposite aid in attachment and efficient penetration into the cell (figure 7). The presence of adapter proteins attached to the clathrin-coated pits help in the attachment of ligands
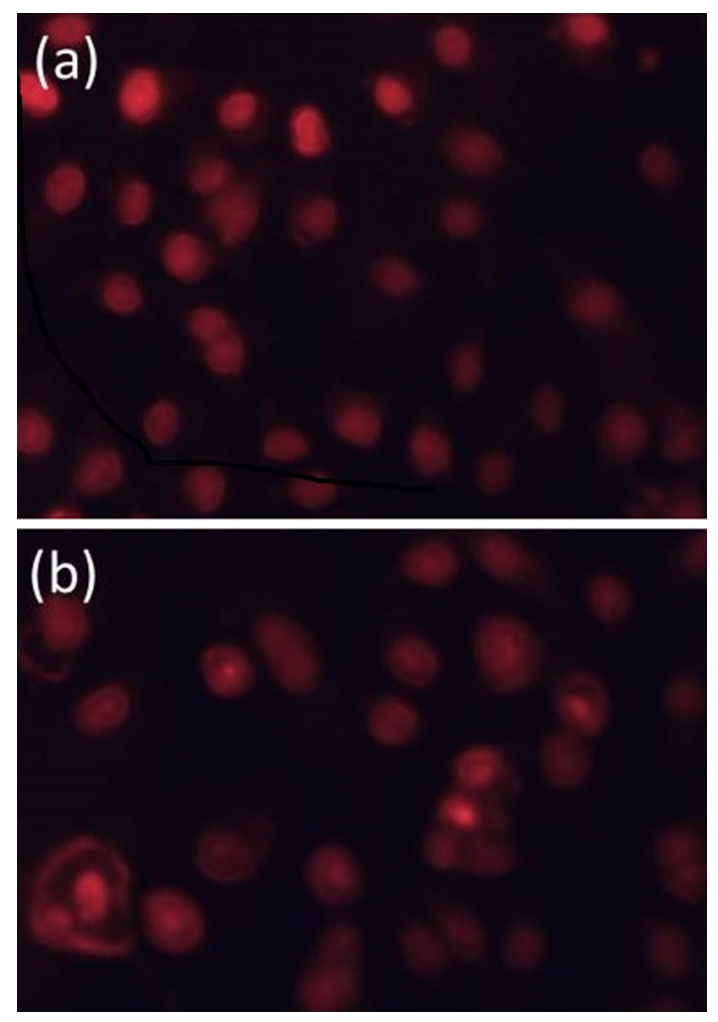

Figure 7. Fluorescent microscopic images of (a) control (HEPTO cell line) and (b) HEPTO cells loaded with $\mathrm{IC}_{50}$ concentration of the selenium nanobiocomposite.

(alcohol, carbonyl O-H, primary, secondary alkyl and allylic carbon) on the surface of nanoparticles to the receptors of the adapter proteins providing sufficient membrane wrapping. The multi-domain GTPase protein dynamin forms a helix around the nanoparticle-enclosed vesicle, facilitating pinching and release of the vesicle into the cytosolic compartment [21].

\section{Conclusions}

The size of the selenium nanobiocomposite was confirmed using SEM analysis ranging between 20 and $30 \mathrm{~nm}$. EDS study provided proof for the very existence and formation of metallic nanobiocomposites with $94.19 \%$ selenium and also provided elemental analysis of the nanocomposite. FTIR and H-NMR provided information on the functional groups and bonds involved in the binding of asparaginase to selenium nanoparticles to form the selenium nanobiocomposite (carbonyl $\mathrm{O}-\mathrm{H}$, primary, secondary alkyl and allylic carbon groups). MTT assay and fluorescent microscopic study confirmed the efficacy in treating various cancers cell lines. Thus, the selenium nanobiocomposite of asparaginase is proved to be a potential anticancer drug for colon cancer. 


\section{Acknowledgements}

This work was financially supported under the scheme Pilot Project Grant for Young Investigators in Cancer Biology (Sanction No. 6242-P96/RGCB/PMD/DBT/GBKR/2015) by the Department of Biotechnology, Government of India.

\section{References}

[1] Le P N, Nguyen N H, Nguyen C K and Tran N Q 2016 Bull. Mater. Sci. 391493

[2] Chakraborty M, Mitra M K and Chakraborty J 2017 Bull. Mater. Sci. 401203

[3] Pranav B V, Dilliganesh T, Vasanth Kumar M, Chamundeeswari M and Baskar G 2013 Bull. Mater. Sci. 361201

[4] Ramaswamy S V P, Narendhran S and Sivaraj R 2016 Bull. Mater. Sci. 39361

[5] Mukundan D, Mohankumar R and Vasanthakumari R 2017 Bull. Mater. Sci. 40335

[6] Chhabria S and Desai K 2016 Encyclopedia of nanoscience and nanotechnology (California, USA: American Scientific Publishers) $\mathrm{p}$ 1-33
[7] Minaev V S, Timoshenkov S P and Kalugin V 2005 J. Optoelectron. Adv. Mater. 71717

[8] Mehdi Y, Hornick J L, Istasse L and Dufrasne I 2013 Molecules 183292

[9] Ahmad M S, Yasser M M, Sholkamy E N, Ali A M and Mehanni M M 2015 Int. J. Nanomed. 103389

[10] Srivastava N and Mukhopadhya M 2015 J. Cluster Sci. 261473

[11] Yazdi M H, Madhavi M M, Setayesh N, Fandyar M S and Shahverdi A R 2013 Daru. J. Pharm. Sci. 211

[12] Ramamuthy C H, Sampath K S, Arunkumar P, Kumar M S, Sujatha V V et al 2013 Bioprocess Biosyst. Eng. 361131

[13] Pi J, Jin H, Liu R, Song B, Wu Q et al 2013 Appl. Microbiol. Biotechnol. 971051

[14] Krall A S, Xu S, Graeber T G, Braas D and Christofk H R 2016 Nat. Commun. 711457

[15] Baskar G, Garrick B G and Chamundeeswari M 2017 J. Inorg. Organomet. Polym. 2787

[16] Malhotra S, Jha N and Desai K 2014 Int. J. Nanotechnol. Appl. 37

[17] Baskar G and Renganathan S 2011 Chem. Pap. 65798

[18] Wriston J C Jr and Yellin T O 1973 Adv. Enzymol. Relat. Areas Mol. Biol. 39185

[19] Bradford M M 1976 Anal. Biochem. 72248

[20] Mossman T 1983 J. Immunol. Methods 6555

[21] Shang L, Nienhaus K, Jiang X, Yang L, Landfester K et al 2014 Beilstein J. Nanotechnol. 52388 